\title{
Ganoderma lucidum Polysaccharide Peptide (GLPP) for the Cancer Treatment
}

\author{
Imam Rasjidi ${ }^{1}$, Christine Susanto ${ }^{2}$ \\ ${ }^{1}$ Oncology division, Siloam Hospital LV \& MRCCC, Department of Obstetry\&Gynecology, \\ Faculty of Medicine, Pelita Harapan University, Tangerang, Indonesia \\ ${ }^{2}$ Faculty of Medicine, Pelita Harapan University, IR Study Center for Reproduction \& Women's \\ Health, Tangerang, Indonesia
}

\begin{abstract}
Ganoderma lucidum mushroom (also known as Ling Zhi in China, Mannetake/Reishi in Japan) has been widely used for thousands of years to prevent and treat various diseases, such as heart disease, diabetes mellitus, viral infection, and cancer. Polysaccharides from Ganoderma lucidum has been extensively investigated for free radical scavenging activity. Both in vivo and in vitro studies suggest that G. lucidum have anti-tumor effects, which mediated by its immunomodulatory, anti-angiogenesis, and cytotoxic effects. Ganoderma lucidum polysaccharide peptide (GLPP) which extracted from Ganoderma lucidum mycelium tissue culture, give the best quality of $\beta$-D-Glucans bioactive compounds. These biologically active glucans interact with receptors on the surface of immune cells such as macrophage and natural killer cell (NK cell) to induce immunomodulatory and tumoricidal effects. However, many studies still need to answer those mechanisms.
\end{abstract}

Key words: Anti-tumor effects, $\beta$-Glucan, Ganoderma lucidum, GLPP, immunomodulatory activity

\section{Ganoderma lucidum Polysaccharide Peptide (GLPP) untuk Terapi Kanker}

\begin{abstract}
Abstrak
Jamur Ganoderma lucidum (dikenal juga dengan nama Ling Zhi di China, atau disebut sebagai Mannetake/ Reishi di Jepang) telah dimanfaatkan secara luas selama ribuan tahun untuk mencegah dan mengobati beragam penyakit, seperti penyakit jantung, diabetes melitus, infeksi virus, bahkan kanker. Polisakarida dari Ganoderma lucidum telah banyak diteliti untuk aktivitas radikal bebasnya. Baik studi in vivo maupun in vitro menyatakan G. lucidum memiliki efek anti tumor, yang dimediasi oleh aktivitas imunomodulator, anti-angiogenesi, dan sitotoksik. Ganoderma lucidum polysaccharide peptide (GLPP) yang diekstrak dari kultur jaringan miselium Ganoderma lucidum memberikan kualitas terbaik dari senyawa bioaktif $\beta$-D-glucans. Senyawa bioaktif glukans ini yang berinteraksi dengan reseptor di permukaan sel-sel imun, seperti makrofag dan NK cell yang dipercaya memberikan efek imunomodulator dan tumorisidal. Meskipun masih diperlukan banyak studi lanjutan untuk menjawab mekanisme dari GLPP.
\end{abstract}

Kata kunci: Anti-tumor, $\beta$-Glucan, GLPP, Ganoderma lucidum, imunomodulator 


\section{Introduction}

According to the World Cancer Report by World Health Organization (WHO), cancer rates could further increase by $50 \%$ to 15 million new cases by $2020 .{ }^{1}$ Chemotherapy and radiotherapy are two routinely used adjuvant treatments for cancer patients in conventional medicine. A variety of adverse events are associated with these two treatments, such as myelosuppression, gastrointestinal discomfort and disorder, alopecia, fatigue, and even cardiac, respiratory and neural toxicity. These side effects have affected patients long-term compliance to medication and have lowered their quality of life. ${ }^{2}$ As a result, many patients turn to choose complementary and alternative medicine. Numerous oncology studies have been initiated in order to find an alternative cancer medication over the past few decades. Ganoderma lucidum (G. lucidum) is one such substance that has been widely studied in Traditional Chinese medicine (TCM). ${ }^{3}$

Ganoderma lucidum mushroom (also known as Ling Zhi in China, Mannetake/ Reishi in Japan) has been widely used for thousands of years to prevent and treat many kinds of diseases. Ganoderma Lucidum are recommended as immune system support supplement in cancer treatment. A large number of chemical compounds have been extracted from the fruiting body, mycelia, or spore. Constituently, the mushroom contains a wide variety of bioactive molecules, including phenol, amino acids, steroids, nucleotides, whereas polysaccharides and triterpenes are the two major groups of components. Each fraction of polysaccharides and triterpenes has more than 100 molecules that have been isolated, most are potent immunomodulators and/or antioxidants and are also chemoprotective and tumoricidal. The polysaccharide extracted from fruit body and mycelia of Ganoderma lucidum have a molecular weight, ranging from 400.0001.000 .000 dalton in their primary structure. ${ }^{4}$ Ganoderma lucidum polysaccharide peptide (GLPP) is a polysaccharide peptide with an average molecular weight of 584.900 dalton and has 17 amino acids (Asp, Thr, Ser, Asn, Glu, Gln, Pro, Gly, Ala, Val, CySH, Ileu, Leu, Tyr, Phe, Lys, His and Arg). The ratio of polysaccharides to peptides is $93.51 \%: 6.49 \%$. The polysaccharides consist of rhamnose, xylose, fructose, galactose, mannose and glucose with molar ratios of 0.793: 0.964: 2.944: 0.167: 0.384: 7.94 and are linked together by $\beta$-glycosidic linkages. ${ }^{5,6}$

GLPP which extracted from Ganoderma lucidum mycelium tissue culture, could give the best quality of bioactive compounds ( $\beta$-DGlucans). $\beta$-D-Glucans, as a major component of GLPP exhibit immunomodulatory activity. Ganoderma $\beta$-D-Glucans are reported to have higher antitumor activity and are better absorbed orally than commercially available synthethic $\beta$-D-Glucans. The biologically active glucans from Ganoderma lucidum consist of a linear backbone of $\beta-(1 \rightarrow 3)$ linked $D$-glucopyranosyl groups with varying degrees of branching from the C6 position. Branches are usually only a single glucose residue, although more than one glucose unit may be present in some glucans. Like a "lock and key", the branching side chains interact with receptors on the surface of immune cells such as macrophage and natural killer cell (NK-cell). The biological activity of $\beta$-DGlucans is influenced by their solubility in water, the molecular size, branching rate, and their forms, the $\beta-(1 \rightarrow 6)$-bonding system in the $\beta-(1 \rightarrow 3)$ major chain.4 In general, larger sizes and more complex $\beta$-glucans such as those derived from Ganoderma lucidum have higher immunomodulating potency. ${ }^{7}$

\section{Pharmacokinetic}

$\beta$-D-Glucans can act on a variety of membrane receptors found on the immune 


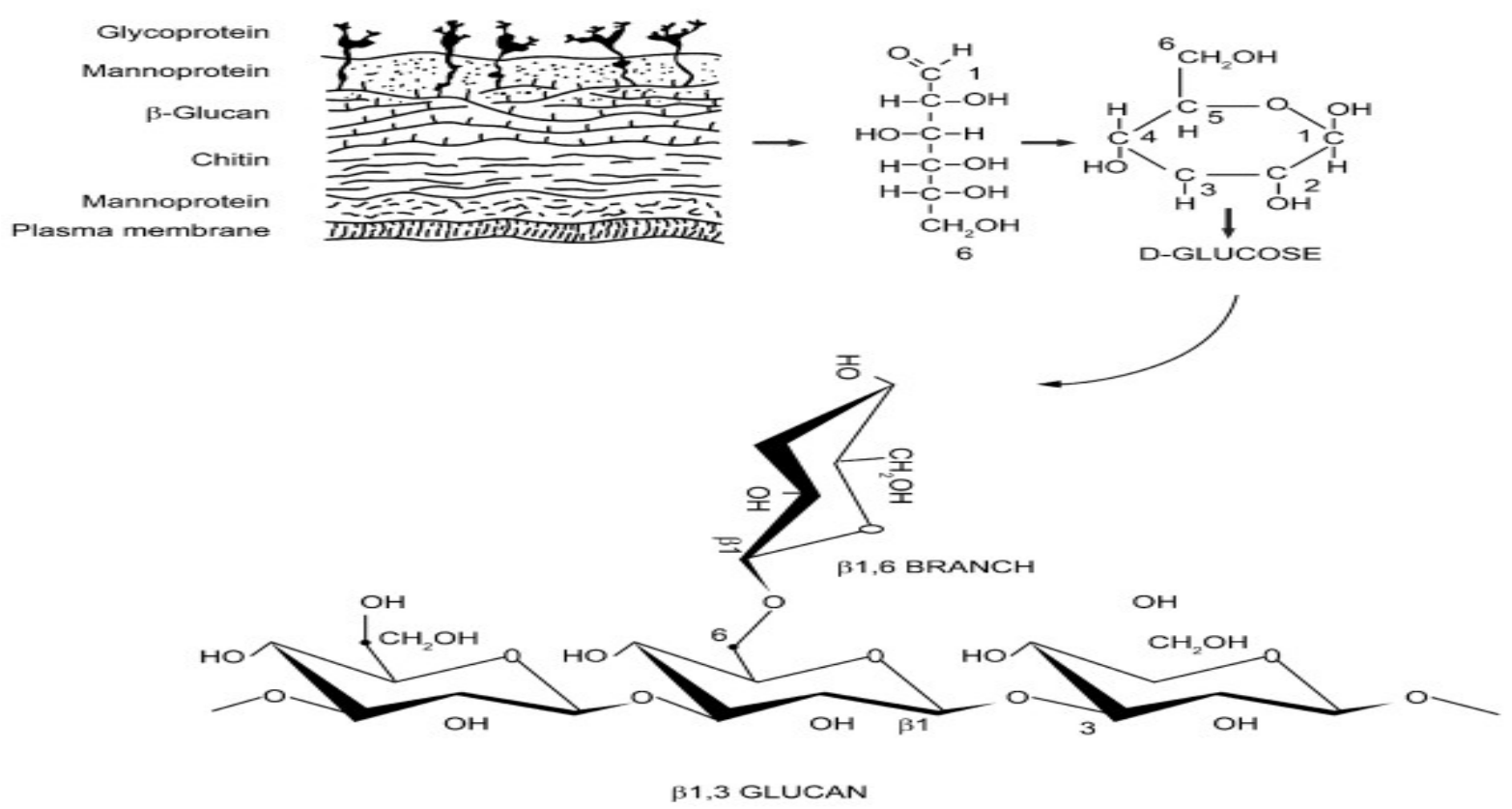

Figure 1 Structure of $\beta$-D-Glucans Ganoderma lucidum

$\beta$-glucan is one of the key components of the fungal cell wall. The basic subunit of the fungal $\beta$-glucan is $\beta$-D-glucose linked to one another by $1 \rightarrow 3$ glycosidic chain with $1 \rightarrow 6$ glycosidic branches.

cells such as: Dectin-1, Complement Receptor 3 (CR3), Toll Like Receptor (TLR), Scavenger Receptor and Lactosylceramide Receptor. $^{7}$ The $\beta$-D-Glucan binding site of CR3 has been mapped to a region of CD11b located C-terminal to the I-domain and its distinct metal ion-dependent adhesion site for the many protein ligands of CR3 such as iC3b, ICAM-1 and fibrinogen. Some of them have shown significant immuno-modulating activities.4 In a study using a suckling rat model for evaluation of the absorption and tissues distribution of enterally administered radioactive labeled $\beta$-D-Glucans, it was found that the majority of $\beta$-D-Glucans was detected in the stomach and duodenum 5 minutes after the administration. This amount rapidly decreased during first 30 minutes. Its transit through the proximal intestine decreased with time with a simultaneous increase in the ileum. ${ }^{7}$

The orally administered $\beta$-D-Glucans were taken up by macrophages in the Peyer patch via the Dectin-1 receptor and subsequently transported to the spleen, lymph nodes, and bone marrow. Within the bone marrow, the macrophages degraded the large $\beta$-D-Glucans into smaller soluble $\beta$-D-Glucans fragments. The small $\beta$-D-Glucans fragments were then released by the macrophages and taken up by the circulating granulocytes, monocytes and dendritic cells. Despite low systemic blood levels (less than $0.5 \%$ ), significant systemic immunomodulating effects in terms of humoral and cellular immune responses were demonstrated. $^{7}$

Pharmacodynamic/Mechanism of Action of GLPP

\section{Immunomodulating Activity}

GLPP are potent stimulators of murine and human macrophages in vitro and in vivo. Among the multiple polysaccharide, active $\beta$-D-Glucans are responsible for the immunomodulating effect. $\beta$-D-Glucans 
appear to act by binding to leucocyte surfaces or serum-spesific proteins such as: Dectin-1, Complement Receptor 3 (CR3), Toll Like Receptor (TLR), Scavenger Receptor and Lactosylceramide Receptor, are leading to activation of macrophages, lymphocyte T-helper, NK-cells, and other effector cells. All of these increase the production of cytokines by the activated effector cells, such as tumor necrosis factor-alpha (TNF- $\alpha$ ), interleukins (IL), interferons (IFN), nitric oxide (NO) and antibodies. ${ }^{4,7}$ The immunomodulating effects of GLPP are extensive, including promoting the function of APC, mononuclear phagocyte system, humoral immunity, and cellular immunity. ${ }^{8}$ Lin ZB (2005) suggested that GLPP potentiated the release of IFN-y from human T cells. GLPP promoted the production of IL-2 in a dose-dependent manner and markedly enhanced the cytotoxicity of cytotoxic T lymphocytes. Moreover, GLPP increased the production of IFN- $\gamma$ mRNA expression in the T-lymphocytes. In addition, treatment of dendritic cells with GLPP

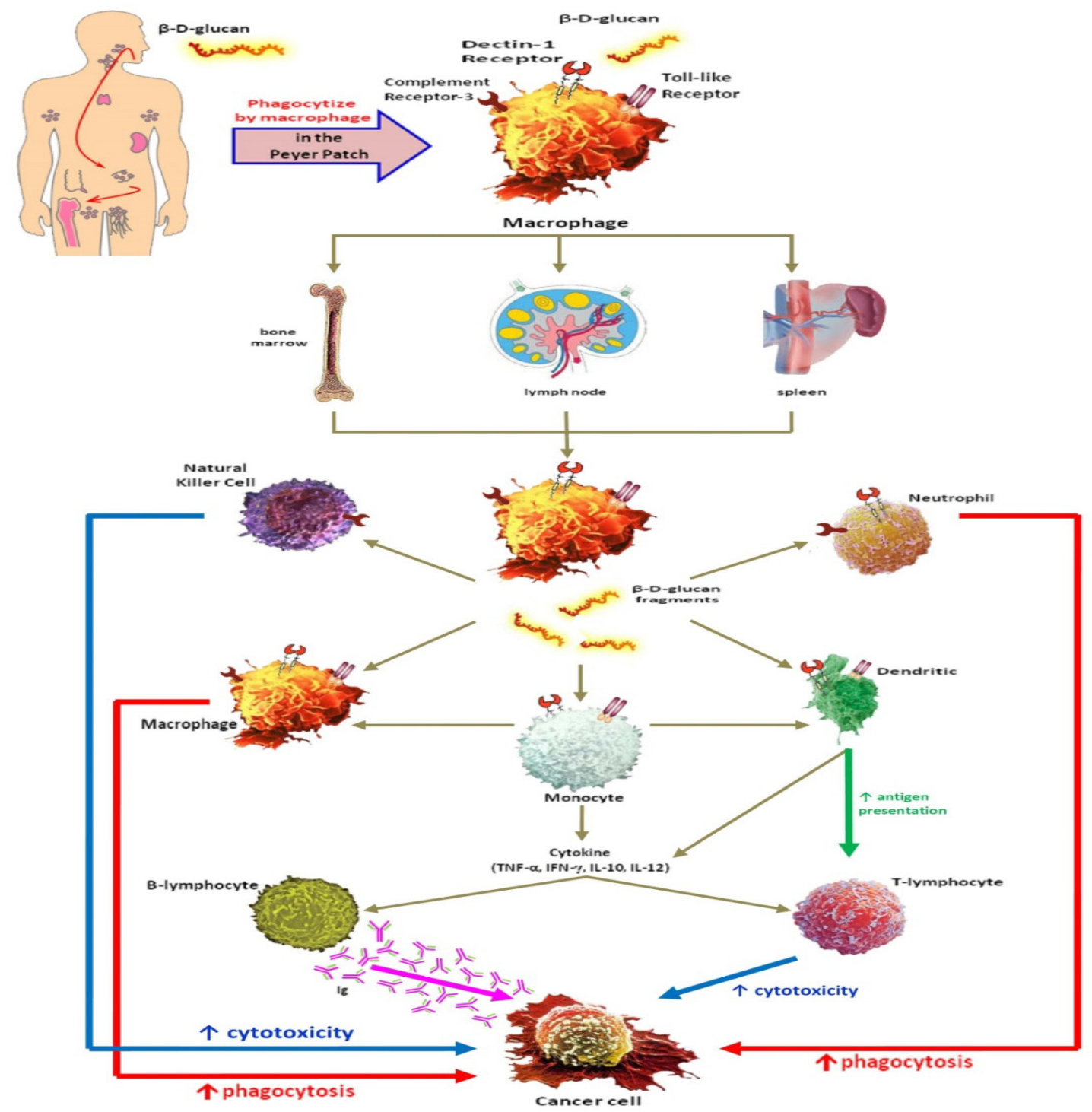

Figure 2 The Uptake and Subsequent Actions of $\beta$-D-Glucans on Immune Cells 
resulted in enhanced $\mathrm{T}$ cell-stimulatory capacity and increased $\mathrm{T}$ cell secretion of IFN-y and IL-10. ${ }^{21}$ Taken together, these data demonstrate that GLPP can effectively promote the activation and maturation of immature DC, activation of $\mathrm{T}$ lymphocytes, suggesting that GLPP may possess a potential in regulating immune responses.

\section{Anti-tumor Effects}

Anti-tumor activity of GLPP had been investigated by several studies. Astudy held by Cao and Lin (2004) showed GLPP anti-tumor effects in sarcoma 180-bearing mice in vivo, tumor proliferation (human lung carcinoma cell line) in vitro and human umbilical cord vascular endothelial cell in vitro. The results showed that GLPP could inhibit tumor cells growth in mice with dose dependency. Further intermediate research by Cao and Lin (2006) elucidated the possible mechanism of GLPP action as anti-tumor. GLPP could reduced B cell lymphoma-2 (Bcl-2) expression and increased Bax expression in human umbilical cord vascular endothelial cell.

GLPP fraction had also been reported to inhibit the proliferation of human colorectal cancer cell SW 480 by inhibiting the synthesis ofDNA and decreasing the formation of radical DPPH (radical scavenging activities). ${ }^{11}$ The

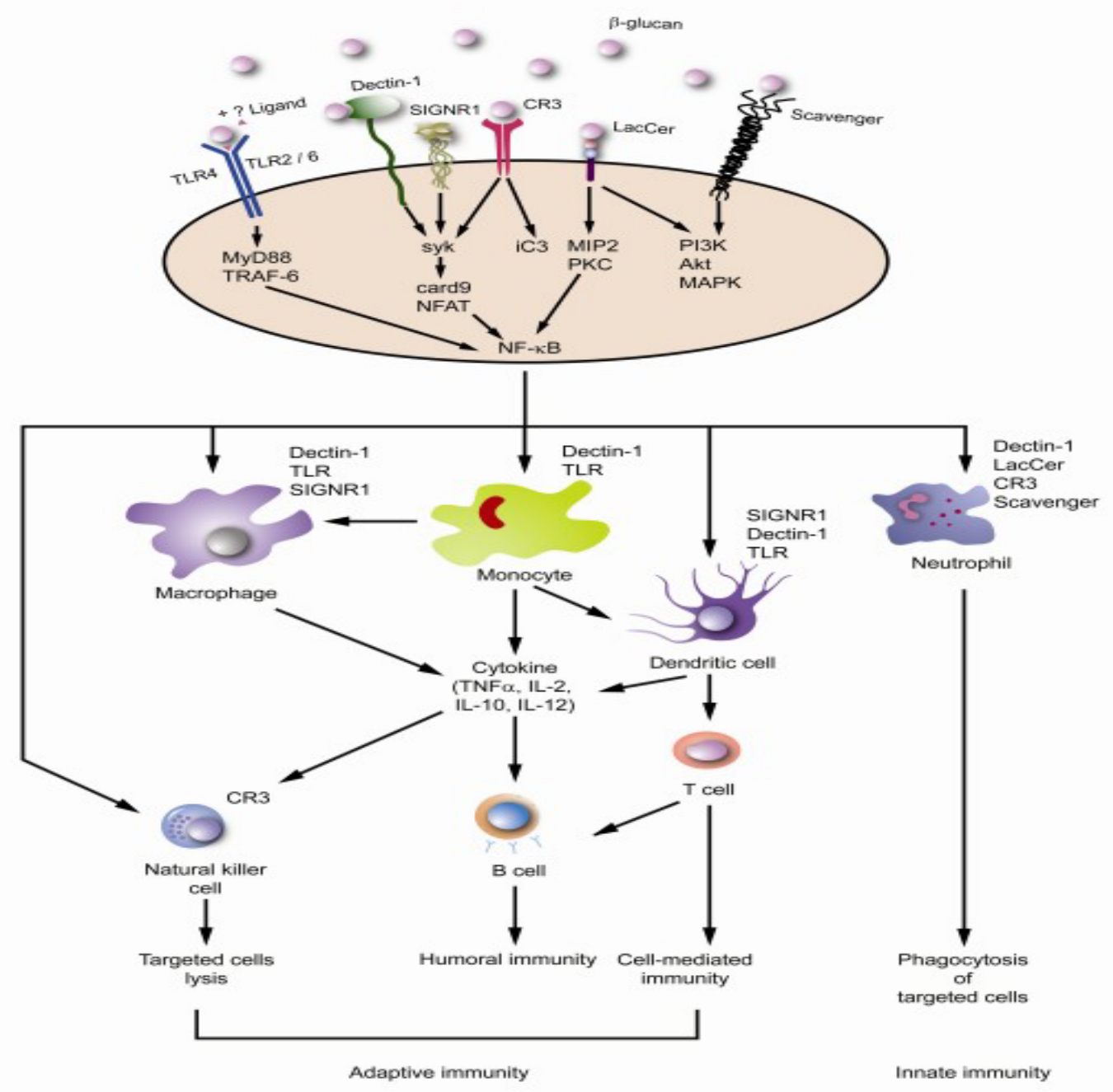

Figure 3 Immune Activation Induced by $\beta$-glucans 
effect of Ganoderma lucidum in leukemic U937 cells has been researched by Liew et al. (1992). Their results indicated that GLPP fraction could significantly inhibit the growth of U937 and induce them to differentiate into mature monocytes/macrophages. Inhibition of the growth of U937 cells can be caused by the raising production level of IL-2 and the activation of NK-cell mediated by GLPP. GLPP induces the differentiation of U937 cells by means of increasing the production of the same cytokine to induce the differentiation of mononuclear leucocyte cells. ${ }^{12}$

$\beta$-glucans are captured by the macrophages via the Dectin-1 receptor with or without TLR$2 / 6$. They are then internalized, fragmented and carried to the marrow and endothelial reticular system and subsequentlyreleased. These small $\beta$-glucan fragments are eventually taken up by the circulating granulocytes, monocytes or macrophages via the complement receptor (CR)-3. The immune response will then be turned on, one of the actions is the phagocytosis of the monoclonal antibody tagged tumor cells.

\section{Chemo-radioprotective Effects}

Recently, many researches are conducted on animal like cyclophosphamide-induces immunosuppressed mice, chronic treatment with low-dose GLPP resulted in accelerated recovery of bone marrow cells, red blood cells (RBC) and white blood cells (WBC), as well as splenic NK cells, enhanced T and $\mathrm{B}$ cell proliferation responses, cytotoxic $\mathrm{T}$ lymphocyte (CTL) activity as well as NK cell and lymphokine activated killer (LAK) cell activity, augmented macrophage phagocytosis and anti-tumor cytotoxicity, and achieved the greatest effect on promoting granulocytopoiesis. Thus, in vivo treatment with low-dose GLPP accelerates the recovery of immunosuppressed mice from leukopenia, myelosuppresion and immunosuppresion, the common conditions associated with cancer chemotherapy. ${ }^{13}$

The higher dose of radiation, the more inhibition of relative splenic weights and biosynthesis of DNA in splenic cells of animals. Moderate dose of $\mathrm{x}$ or X-ray irradiation will affect the weight of thymus and spleen. Radiation exposure clearly induces acute immunodeficiency in animals and humans. The decrease of stem cells in hematopoietic organs is believed to be a major factor in this immune deficiency. Radiation induced a reduction in splenocyte and thymus weight, and as result, CD4 and CD8 cells in the spleen also were decreased. Ionizing radiation could also depress cellular immunity. Chen W, et al (1995) showed that GLPP increased the thymus recovery from radiation and promoted splenocyte proliferation, therefore repairing the damage of subset T-cells in the spleen of $\gamma$-irradiated mice. ${ }^{14}$ Treatment with glucans in mice* has been shown to increase survival and improve hematopoietic regeneration after irradiation and that the glucans act directly on committed myeloid progenitors to improve hematopoiesis.15 (*inbred male 6-8-weekold (body weight 18-22g) BALB/c (H-2 d) mice (Grade II, certificate No scxk 11-000004) and BALB/c nude mice (Grade III, certificate No scxk 11-00-0010, purchased from Department of Experimental Animals, China, in accordance to Institute Ethical Committee for Experimental Use of Animals) Beside to inhibit myelosuppresion and immunosuppresion at chemo-radiotherapy, GLPP could also prevent chemotherapeutic multidrug resistance (MDR). MDR, a major cause of cancer treatment failure, is a phenomenon whereby cancer cells develop resistance to a wide variety of chemotherapeutic drugs. This MDR has been associated with the overexpression of P-glycoprotein (P-gp) or MDR-associated protein (MRP), two transmembrane transporters that act as pumps to remove toxic 
drugs from tumor cells. The reversal effect of GLPP on MDR in K562/ADM cell line (K562 cell line that is resistant to adriamycin) has been researched by Li, et al (2008). They showed that GLPP could reverse the sensitivity of K562 cell line to adriamycin, GLPP could downregulate the P-gp and MRP functional expression in the K562/ADM cells compared to the control group (without treatment with GLPP). Furthermore, the effect of GLPP on ADM accumulation in K562/ADM cells has been tested. The result showed that GLPP increased the accumulation of adriamycin in K562/ADM cell line compared to the control group (without treatment with GLPP). ${ }^{16}$

MDR also a major problem in small cell lung cancer (SCLC). One of the study tested the effects of Ganoderma lucidum mycelium on drug-sensitive (H69) and multi-drug resistant (VPA) human SCLC cells. Cells treated with the initial concentration (IC50) of cyotoxic Ganoderma lucidum mycelium and analyzed by flow cytometry-PI staining showed increased in S phase. When comparing untreated controls or SCLC cells treated with extracts of non-cytotoxic Ganoderma species, cells treated with extracts of cyotoxic Ganoderma lucidum mycelium responded with an induction of apoptosis similar to cells treated with the chemotherapeutics drugs etoposide and doxorubicin. This study results showed that in both drug-sensitive and drug-resistant SCLC cells, pre-incubation with active Ganoderma lucidum mycelium extracts indeed significantly lowered the IC50 dose of etoposide or doxorubicin. ${ }^{17}$

\section{Clinical Study of GLPP}

Ganoderma lucidum has been collected and used for hundreds of years in many countries. Some clinical study of GLPP on advanced stage cancer had been held. Gao, et al (2003) studied the effects of Ganoderma lucidum polysaccharide extract on the immune functions in 34 advanced stage cancer patients. For the inclusion criteria, Gao, et al choose the advanced stage cancer arising from various tissues with ECOG performances status of 0-2 and a projected life expectancy of $\geq 12$ weeks. The patients also have adequate bone marrow function, renal function and liver function and informed consent for participation. The patients were treated with $1800 \mathrm{mg}$, three times daily orally before meal for 12 weeks. Each capsule contained 600 mg extract of Ganoderma lucidum, with $25 \%$ (w/w) crude polysaccharides.

Treatment of GLPP for 12 weeks resulted in a significant increase in the mean plasma concentrations of IL-2, IL-6 and IFN- $\gamma$, whereas the levels of IL- 1 and TNF- $\alpha$ were significantly decreased. The inhibitory effects of GLPP on TNF- $\alpha$ production may result in beneficial effects (e.g. improved life quality) in advanced stage cancer patients. Increased TNF- $\alpha$ has been thought to contribute to cancer cachexia that is manifested by bodyweight loss, chronic nause, fatigue, insomnia and profuse sweating. The mean absolute number of CD56+ cells was significantly increased after 12 weeks treatment of GLPP, whereas the baseline levels, with the CD4:CD8 T cell ratios unchanged. In addition, GLPP treatment resulted in a significant increase in the mean NK activity compared to baseline $\quad(34.5 \pm 11.8 \%$ vs $26.6 \pm 8.3 \%){ }^{20}$

Gao, et al also do a randomized, placebo controlled, multicenter study of Ganoderma lucidum polysaccharide extract in 68 patients with advanced lung cancer. Patients were randomized to be given Ganoderma lucidum polysaccharide (GLPP) $(n=37)$ or placebo $(n=31)$ for 12 weeks. Treatment with GLPP gave stable disease (SD) in $13(13 / 37,35.1 \%)$ lung cancer patients at the 12 week evaluation point, which was significantly greater than that of control group $(7 / 31,22.6 \%)$. In 32 assessable cancer patients, treatment of GLPP resulted in a significant increase ( $>10$ scores) 
in the Karnofsky Performance Status (KPS) score in 16 patients $(50 \%), 4$ patients $(14.3 \%)$ obtained significant increase in the KPS score in the control group with 29 assessable patients; and $9(28.1 \%)$ and $7(21.9 \%)$ patients receiving GLPP had unchanged and reduced KPS score, respectively.

Palliative therapy effects on cancer-related symptoms such as fever, cough, weakness, sweating and insomnia have been observed in $43.8-84.4 \%$ of cancer patients receiving GLPP, but only a small percentage (10.7$42.9 \%$ ) of cancer patients who is receiving placebo demonstrated an improvement cancer-related symptoms. Administration of GLPP for 12 weeks resulted in significant increase in lymphocyte mitogenic reactivity to concanavalin $\mathrm{A}, \mathrm{CD} 3$ percentage, and NK cell activity; a marginal increase in CD4 percentage and CD4/CD8 ratio; buat a marginal reduction of CD8. However all these immune parameters remained unchanged or decreased in the control group. ${ }^{18}$

Clinical study of 143 patients with advanced cancer treated with GLPP for 12 weeks also show the improvement of palliative effects of cancer-related symptoms such as sweating and insomnia. The Functional Assessment of Cancer Therapy General (FACT-G) scores improved in 23 patients, were unchanged in 5 patients, and decline in 1 patient. However, in the group of 32 patients with SD for 12 weeks or more, GLPP significantly increased lymphocyte mitogenic reactivity to concanavalin A and phytohemagglutinin by $28 \pm 7.3 \%$ and significantly enhanced NK cell activity by $25 \pm 5.9 \%{ }^{19}$

\section{Conclusion}

This systemic review demonstrated that GLPP has antitumor effect activities beyond that of the immune system with the induction of chemopreventive activity and suppresion the cancer proliferation. Ganoderma lucidum preparations can be administered in order to counter the immunosuppressive effect of chemo/radiotherapy, especially in terms of T-lymphocyte depletion. Similar to other natural remedies, G. lucidum is well-tolerated by cancer patients leading to better quality of life and a relatively improved Karnofsky score. No severe toxicity has been observed according to current evidence.

\section{Acknowledgements}

Thanks to Puspitoratri Hardini, S.Farm., Apt, drh. Debora Natalia, and also big appreciation to Christine Susanto, MD for assist these data collection, process, and analysis.

\section{References}

1. Steward BW, Kleihues P. World cancer report 2014, World Health Organization. Lyon: IARC Press; 2014.

2. Polovich M, Whitford JM. Chemotherapy and biotherapy guideline recommendations for practice. Pittsburgh: Oncology Nursing Society; 2009.

3. Boh B, Berovic M, Zhang J, ZhiBin L. Ganoderma lucidum and its pharmaceutically active compounds. Biotechnol Annu Rev. 2007;13:265-301. doi:10.1016/S1387-2656(07)13010-6

4. Zhou S, Gao Y. The immunomodulating effects of Ganoderma lucidum (Curt.: Fr.) P. Karst (Ling Zhi, Reishi Mushroom) (Aphyllophoromycetideae). Inter J Med Mushrooms. 2002;4(1):10. doi: 10.1615/ IntJMedMushr.v4.i1.10

5. Zhang H, Lin ZB. Hypoglycemic effect of Ganoderma lucidum polysaccharides. Acta Pharmacol Sin. 2004;25(2):191-5.

6. Wang YY, Khoo KH, Chen ST, Lin $\mathrm{CC}$, Wong $\mathrm{CH}$, Lin $\mathrm{CH}$, et al. Immunomodulating antitumor activities of Ganoderma lucidum (Reishi) polysaccharides. US: Bioorg. Med. 
Chem; 2006.

7. Chan GFC, Chan WK, Sze DMY. The effects of $\beta$-Glucan on human immune and cancer cells. J Hematol Oncol. 2009; 2(25):1-11. doi:10.1186/1756-8722-2-25

8. Lin ZB. Cellular and molecular mechanisms of immuno-modulation by Ganoderma lucidum. J Pharmacol Sci. 2005;99(2):144-153. doi: 10.1254/jphs. CRJ05008X

9. Cao QZ, Lin ZB. Antitumor and antiangiogenic activity of Ganoderma lucidum polysaccharides peptide. Acta Pharmacol Sin. 2004;25(6):833-8.

10. Cao QZ, Lin ZB. Ganoderma lucidum polysaccharides peptide inhibits the growth of vascular endothelial cell and the induction of VEGF in human lung cancer cell. Life Sci. 2006;78:1457-63. doi:10.1016/j.lfs.2005.07.017

11. Xie JT, Wang CZ, Wicks S, Yin JJ, Kong $\mathrm{J}$, Li J, et al. Ganoderma lucidum Extracts inhibits proliferation of sw 480 human colorectal cancer cells. Exp Oncol. 2006;28(1):25-9.

12. Lieu CW, Lee SS, Wang SY. The effect of Ganoderma lucidum on induction of differential in leukemic U937 cells. Anticancer Res. 1992;12(4):1211-6.

13. Zhu XL, Chen AF, Lin ZB. Ganoderma lucidum polysaccharide enhance the fuction of immunological effector cells in immunosuppressed mice. $\mathrm{J}$ Ethnopharmacol. 2007;111(2):219-26. doi:10.1016/j.jep.2006.11.013

14. Chen WC, Hau DM, Wang CC. Effects of Ganoderma lucidum and krestin on subset T-cell in spleen of gamma-irradiated Mice. Am J Chin Med. 1995;23(3-4):289-98. doi: 10.1142/S0192415X95000341

15. Weitberg AB. A phase I/II trial of beta$(1,3) /(1,6)$ D-glucan in the treatment of patients with advanced malignancies receiving chemotherapy. J Exp Clin Cancer Res. 2008;19(27):40. doi: 10.1186 /1756-9966-27-40

16. Li WD, Zhang BD, Wei R, Liu JH, Lin ZB. Reversal effect of Ganoderma lucidum polysaccharide on multidrug resistance in K562/ADM cell line. Acta Pharmacol Sin. 2008;29(5):620-7.

17. Sadava D, Still DW, Mudry RR, Kane SE. Effect of Ganoderma on drugsensitive and multidrug-resistant smallcell lung carcinoma cells. Cancer Lett. 2009;277(2):182-9. doi:10.1016/j.canlet. 2008.12.009

18. Gao Y, Dai X, Chen G, Ye J, Zhou S. A randomized, placebocontrolled multicenter study of Ganoderma lucidum (W. Curt.:Fr.) Llyod (Aphyllophoromycetidae) polysaccharides (Ganopoly) in patients with advanced lung cancer. Intern J Med Mushrooms. 2003;5(4):369-81. doi: 10. 1615/InterJMedicMush.v5.i4.40

19. Gao Y, Zhou S, Chen G, Dai X, Ye J. A phase I/II study of Ganoderma lucidum (Curt.:Fr.) P. Karst. extract (Ganopoly) in patients with advanced cancer. Intern J Med Mushrooms. 2002;4(3):207-14. doi: 10.1615/IntJMedMushr.v4.i3.30

20. Gao Y, Zhou S, Jiang W, Huang M, Dai $\mathrm{X}$. Effects of ganopoly (A Ganoderma lucidum polysaccharides extract) on the immune functions in advanced-stage cancer patients. Immunol Invest. 2003; 32(3):201-15.

21. Lin YL, Liang YC, Lee SS, Chiang BL. Polysaccharide purified from Ganoderma lucidum induced activation and maturation of human monocytederived dendritic cells by the NF-kB and p38 mitogen-activated protein kinase pathways. J Leukoc Biol. 2005;78(2): 533-43. doi:10.1189/jlb.0804481 